\title{
Associations between C-reactive protein and all- cause mortality among oldest old adults in Chinese longevity areas: A community-based cohort study
}

\section{Pei-Liang Chen}

School of Public Health, Southern Medical University

Hai-Lian Yang

School of Public Health, Southern Medical University

\section{Zhao-Jin Cao}

National Institute of Environmental Health, Chinese Center for Disease Control and Prevention

\section{Xin Cheng}

School of Public Health, Southern Medical University

\section{Feng Zhao}

National Institute of Environmental Health, Chinese Center for Disease Control and Prevention

\section{Xi-Ru Zhang}

School of Public Health, Southern Medical University

\section{Yue-Bin Lv}

National Institute of Environmental Health, Chinese Center for Disease Control and Prevention

\section{Fu-Rong Li}

School of Public Health, Southern Medical University

\section{Ying-Li Qu}

National Institute of Environmental Health, Chinese Center for Disease Control and Prevention Zhao-Xue Yin

National Institute of Environmental Health, Chinese Center for Disease Control and Prevention Ling Liu

National Institute of Environmental Health, Chinese Center for Disease Control and Prevention Ying-Chun Liu

National Institute of Environmental Health, Chinese Center for Disease Control and Prevention Jin-Hui Zhou

National Institute of Environmental Health, Chinese Center for Disease Control and Prevention

\section{Chen Mao}

School of Public Health, Southern Medical University

\section{Xiao-Ming Shi}

National Institute of Environmental Health, Chinese Center for Disease Control and Prevention

Xian-Bo Wu ( $\nabla$ wuxb1010@hotmail.com ) 
Research article

Keywords: C-reactive protein, all-cause mortality, oldest old

Posted Date: July 8th, 2019

DOl: https://doi.org/10.21203/rs.2.11072/v1

License: (c) (i) This work is licensed under a Creative Commons Attribution 4.0 International License. Read Full License 


\section{Abstract}

Background: Higher C-reactive protein (CRP) levels have been proposed as a predictor of all-cause mortality in many existing studies from multiple populations, but the association for the oldest old adults (aged 80 and older) remains unclear. Objective: To examine the association between CRP and all-cause mortality among the oldest old Chinese adults. Design: This is a prospective, community-based longitudinal cohort study with 2206 adults aged 80 years old and older with available CRP test results. Cox proportional hazards regression models were used to estimate hazard ratios (HRs) with $95 \%$ confidential intervals $(95 \% \mathrm{Cls}$ ) for all-cause mortality according to CRP quartiles, adjusting for potential confounders. Results: The median age of the participants was 93 years old, and the median CRP concentration was $1.13 \mathrm{mg} / \mathrm{L}$ at baseline. During a median follow-up period of 36.7 months, 1106 deaths were verified. After full adjustment for potential confounders, a high CRP concentration was positively associated with an increased risk of all-cause mortality. Compared with the lowest quartile, the fully adjusted HRs of the second, third, and fourth quartiles were 1.17 (95\% Cl: $0.94,1.46), 1.28$ (95\% Cl: 1.01 , $1.61)$, and 1.50 (95\% Cl: $1.20,1.87)$, respectively. The association of CRP with all-cause mortality was likely modified by smoking status $(P=0.011)$. Conclusions: Our study indicated that a high CRP concentration was likely to be a prospective factor predicting death among the oldest old adults. Future studies investigating additional factors of disease and aging processes are needed to obtain a better understanding of the mechanisms.

\section{Background}

Inflammation has been studied to be the role of a wide range of aging-related diseases [1], such as atherosclerosis and coronary artery disease [2], diabetes [3], Alzheimer's disease [4] and cancer [5]. Inflammaging, a description of low-grade, chronic, systemic inflammation in aging, is a highly significant risk factor for both morbidity and mortality in elderly people, as most if not all age-related diseases share inflammatory pathogenesis. Nevertheless, the precise etiology of inflammaging and its potential causal role in contributing to adverse health outcomes remain largely unknown [6,7]. Chronic, low-grade elevations in markers of inflammation, such as C-reactive protein (CRP), are potent risk factors for allcause mortality [8].

CRP, an acute-phase protein produced predominantly by hepatocytes, is a sensitive and exquisitely systemic marker of inflammation [9]. CRP has been commonly assayed for infections[10], in-hospital complications[11], prognosis influences[12] and aging-related health outcomes in clinical applications, especially cardiovascular and metabolic disease risk[13, 14].Higher CRP levels have been proposed as a predictor of all-cause mortality in many [15-26] but not all studies [27]. Inconsistent results may exist due to sex, ethnic or age differences in the populations, and the strength of the association also varied across studies. Moreover, these findings are based on the general population, but the oldest old adults (octogenarians, nonagenarians and centenarians) remain underrepresented. The classic risk markers for disease and mortality might not be effective in the oldest old population [28]. 
Therefore, we conducted the present study to prospectively examine whether CRP is associated with allcause mortality among the oldest old adults based on datasets from the Chinese Longitudinal Healthy Longevity Survey (CLHLS) in longevity areas.

\section{Methods}

\section{Design, study setting, and participants}

This is a perspective, community-based longitudinal cohort study. Participants were recruited in the sixth wave (2012) and the seventh wave (2014) of CLHLS from eight longevity areas selected by the Chinese Society of Gerontology. The densities of oldest old adults are higher (especially for centenarians) in longevity areas than in other areas. These areas include Chen Mai County (Hainan Province), Yong Fu County (Guangxi Province), Ma Yang County (Hunan Province), Zhong Xiang City (Hubei Province), Xia Yi County (He Nan Province), San Shui City (Guangdong Province), Lai Zhou City (Shandong Province), and Ru Dong County (Jiangsu Province). Overall, 2206 participants were enrolled at baseline and follow-up in 2014 and 2017, respectively. We included all adults aged 80 years or older with available results of CRP tests, and 269 of these adults were lost to follow-up (Figure 1). The study was approved by the biomedical ethics committee of Peking University. All participants included in CLHLS provided informed consent. More details of CLHLS have been previously described [29].

\section{Measurement of CRP}

Venous blood samples were obtained from the participants by collecting in heparin anticoagulant vacuum tubes. CRP concentration was generally measured through a high-sensitivity immunoturbidimetry assay, and all blood biochemistry tests were conducted by the central clinical lab at Capital Medical University in Beijing.

\section{Measurement of all-cause mortality}

We verified the survival status of all participants at baseline during follow-up surveys in 2014 and 2017 . Date of death was inquired and ascertained from family members or caregivers of the deceased. The survival time for participants was calculated from the date they enrolled in our study to the date of death. For survival, survival time was identified as right-censored at the date of the latest follow-up. Those who could not be found and contacted were recorded as "lost to follow-up".

\section{Measurement of covariates}

Covariate information was collected via face-to-face structured questionnaires and biochemistry assays. Covariates in our analyses included sociodemographic information (age, sex, education and residence), 
lifestyle (smoking status, alcohol consumption, exercise and dietary habits), physical examination (body mass index [BMI], systolic blood pressure [SBP] and diastolic blood pressure[DBP]), medical history (hypertension, diabetes and cardiovascular disease [CVD]), Mini-Mental State Examination (MMSE) score, frailty status and biochemical indicators (plasma cholesterol, triglycerides and fasting blood glucose).

Dietary habits include vegetable intake, fruit intake, meat intake, and exercise. For the frequencies of food intakes, "almost every day" or "often" were categorized into "often" and "occasionally" and "rarely or never" was categorized into "not often"; for exercise, "yes" or "no" was determined from the question, "Do you do exercises regularly at present?". MMSE [30] is a practical scale for grading the cognitive state, and the oldest old adults in China with MMSE scores below 24 could be defined as having cognitive impairment [31]. Frailty status was classified according to the Study of Osteoporotic Fractures (SOF) index [32] using three components as follows: 1 ) weight loss $\left(\mathrm{BMl}<18.5 \mathrm{~kg} / \mathrm{m}^{2}\right) ; 2$ ) inability to rise from a chair without using arms; 3 ) reduced energy level, defined by a "yes" response to the question, "For at least the last 6 months have you been limited in activities people usually do, because of a health problem?" The status was categorized as robust (no components), prefrail ( 1 component) or frail ( 2 or 3 components), which has been shown to be an applicable indicator of biological age in Chinese older adults [33]. For the medical history, hypertension was defined as $S B P \geq 140 \mathrm{mmHg}$ and/or DBP $\geq 90 \mathrm{mmHg}$ based on 2018 Chinese guidelines for the management of hypertension [34]; diabetes was defined as fasting blood glucose $\geq 7.0 \mathrm{mmol} / \mathrm{L}$ based on National guidelines for the prevention and control of diabetes in primary care [35]for the Chinese population; CVD was determined by the self-report of the participants.

\section{Statistical analysis}

A table for baseline characteristics was generated using descriptive statistics stratified by CRP quartiles $(\mathrm{mg} / \mathrm{L})$. Continuous data were described by medians and interquartile ranges (IQR), and categorical data were described by frequencies and percentages (\%). Hypotheses regarding differences in characteristics across quartiles of CRP were analyzed using linear regression for continuous variables and $\chi^{2}$ tests for categorical variables.

Kaplan-Meier curves were generated for the quartiles of CRP concentrations, and log-rank tests were used to compare different quartile subgroups. Cox proportional hazards regression models were used to estimate hazard ratios (HRs) with $95 \%$ confidential intervals ( $95 \% \mathrm{Cls}$ ) of mortality by CRP quartiles, with the lowest quartile (Q1) as the reference group. The Cox models were adjusted for potential confounders that may be associated with both CRP concentrations and mortality. The following three models with different adjustments were used: 1 ) the first model (model 1) tested the association between CRP and mortality, controlling for age and sex; 2 ) the second model (model 2) was further adjusted for other baseline characteristics, namely, education time ( 0 year or $\geq 1$ year), residence status (rural or urban), smoking status (current or not current), alcohol consumption (current or not current), vegetable intake (often or not often), fruit intake (often or not often), meat intake (often or not often), and exercise (yes or 
no); and 3) the third adjusted model (model 3) was further adjusted for physical examination, disease status and biochemical indicators. The aforementioned covariates included BMI (continuous), MMSE scores (continuous), frailty status (frail, prefrail, robust), hypertension (yes or no), diabetes (yes or no), CVD (yes or no), cholesterol (continuous), and triglycerides (continuous). Model 3 was considered to be fully adjusted. Tests of linear trends were performed by treating the median values for each quartile of CRP as a continuous variable.

The subgroup analyses of HRs for mortality by each $10 \mathrm{mg} / \mathrm{L}$ increase in CRP were performed according to sex (men or women), age (80+ years, $90+$ years, and $100+$ years), education, residence, smoking status, alcohol consumption, fruit intake, meat intake, vegetable intake, exercise, BMI $\left(<18.5 \mathrm{~kg} / \mathrm{m}^{2}, \geq 18.5\right.$ and $<24 \mathrm{~kg} / \mathrm{m}^{2}, \geq 24 \mathrm{~kg} / \mathrm{m}^{2}$ ), MMSE ( $<24$ or $\geq 24$ ), frailty status. Possible interaction effects were explored by groups from the abovementioned characteristics, including interaction terms in Cox models.

Analyses were conducted using Stata version 14.0 (College Station, Texas). A P-value $<0.05$ was considered statistically significant.

\section{Results}

\section{Baseline characteristics}

Among 2206 individuals, the median age of participants was 93 years (IQR: 86-100 years). A total of 1417 were women $(64.23 \%)$, and 1905 were living in rural areas (87.19\%). Baseline characteristics are summarized in Table 1 by CRP quartiles. The median CRP concentration was $1.13 \mathrm{mg} / \mathrm{L}$ (IQR: 0.46-2.92 $\mathrm{mg} / \mathrm{L}$ ), with no significant associations with age or residence. Of those in the highest quartile of CRP, a greater proportion of the adults were female and frail, inclined to have less fruit and meat intakes, reported to have no hypertension or CVD, and tended to have lower levels of cholesterol and glucose.

\section{CRP and all-cause mortality}

During a median follow-up period of 36.7 months (IQR: 19.3-46.9 months), a total of 1106 all-cause deaths occurred (male: 380; female: 726). Figure 2 displays the Kaplan-Meier curves for all-cause mortality by quartiles of CRP. The log-rank tests showed significant differences in all-cause mortality among different levels of CRP $(P=0.000)$. Table 2 presents the association between CRP and mortality. Compared with the lowest quartile, the fully adjusted HRs of the second, third, and fourth quartiles were 1.17 (95\% Cl: 0.94, 1.46), 1.28 (95\% Cl: 1.01, 1.61), and 1.50 (95\% Cl: 1.20, 1.87), respectively (Table 2). The risk of all-cause mortality increased with elevated CRP $(P<0.001)$. A supplementary analysis was also conducted based on the recommendation for relative risk categories of CRP levels [36], namely, $<1.0$ $\mathrm{mg} / \mathrm{L}$ (low risk), 1.0-3.0 mg/L (average risk) and $>3.0 \mathrm{mg} / \mathrm{L}$ (high risk). Individuals with CRP $>3.0 \mathrm{mg} / \mathrm{L}$ had a significantly higher risk (HR: $1.39 ; 95 \% \mathrm{Cl}: 1.15,1.70)$ of all-cause mortality even after full adjustment. 


\section{Subgroup analyses}

Subgroup analyses stratified by major confounders are presented in Table 3. The HRs showed similar results with no significant differences across most subgroups defined by age, sex, education, residence, drinking status, vegetable intake, fruit intake, meat intake, exercise, BMI, frailty status, MMSE scores. However, a significant interaction from smoking status was noted $(P=0.011)$.

\section{Discussion}

In this population-based 6-year follow-up study of oldest old adults living in Chinese longevity areas, the participants with high CRP concentrations had an increased risk of mortality, even after adjusting for potential confounders. Stratified by quartiles, the highest quartile of CRP showed a statistically significant difference compared with the lowest quartile after full adjustment. The association of CRP with all-cause mortality was less likely modified by sociodemographic factors, physical examinations, biochemical indicators and most lifestyle factors, except for smoking status.

Our findings are consistent with previous studies demonstrating positive associations between CRP and all-cause mortality, which are significant at higher levels of the CRP distribution [15,19-21,23-26]. The estimated value might differ by ethnicity because Asian populations tend to have a lower CRP level than Western populations [37,38]. A study [39] with 11623 middle-aged Chinese individuals categorized three groups based on CRP levels ( $<1.0,1.0-3.0$, and $>3.0)$ and obtained the result that the HR for all-cause mortality in the $>3.0$ group was $2.64(95 \% \mathrm{Cl}: 1.74,4.01)$. This difference inferred that the estimate might wane with age or that the sample size of our current study was not sufficient to provide power to detect a difference.

It is also important to note that sex was not a modifier in our study. Some studies showed a positive association in both sexes [8,23], while significant differences appeared to exist in a single sex (mostly male $[27,40,41])$. However, whether males or females are at a greater risk remains controversial $[8,23,41,42]$. The differential effect of CRP in predicting all-cause mortality risk by sex warrants further investigation. Smoking status is another novel point in which significant interaction was found. However, the estimate seemed to be stronger in nonsmokers, though both stratifications showed no significant differences. One explanation is that inflammation adaption might occur in the human body during the period of habitual smoking, resulting in a lower hazard to current smokers than to those who did not smoke during the same period. From another consideration, a limited sample size leads to a lack of statistical significance in the estimate, and even interaction exists. Moreover, evidence shows that smoking cessation does not reduce CRP [43], but in our study, we did not take this into account during grouping, which might cause misclassification bias. The interaction observed by smoking status warrants further research.

Potential limitations of the current study should be considered in evaluating our results. Our study is observational in nature, and we cannot rule out the possibility of reverse causality; therefore, CRP might 
also be a consequence of diseases rather than a cause. Moreover, the residual confounded by other unmeasured or unknown factors likely exists and potentially results are biased in an unknown direction despite our full adjustment in analyses. Additionally, since information on the subtype of death was not collected in the CLHLS, in-depth analyses based on cause-specific mortality are necessary but unable to conduct. Finally, similar to most other studies, the fact that CRP was measured only once at baseline is a potential limitation because random fluctuation in this parameter over time would tend to increase the variance in the data; how trajectories of CRP may influence mortality remains undetermined.

Despite these limitations, this study has noteworthy strengths when compared to prior research. Above all, our findings were based on a prospective study with integrated and detailed baseline, outcome, and blood sample data. The robustness of the outcomes measured and the large sample size of the oldest old adults increases the relevance of our findings. For representativeness, it is believed that communitydwelling older adults are more typical due to the dominance of family care in the Chinese society. A distinguishing feature of this study is that all of the longevity areas we investigated provided a distinct population of oldest old adults, which broadens the evidence from existing research with a unique age spectrum.

\section{Conclusion}

Our analyses indicated that high CRP concentrations are likely to be a prospective factor predicting death among the oldest old adults. CRP may be more useful clinically in identifying higher risk populations for all-cause mortality. Future studies investigating additional factors of disease and aging processes are needed to conduct a better understanding of the mechanisms.

\section{Abbreviations}

$\mathrm{BMI}$, body mass index; Cl, confidential interval; CLHLS, the Chinese Longitudinal Healthy Longevity Survey; CRP, C-reactive protein; CVD, cardiovascular disease; DBP, diastolic blood pressure; HR, hazard ratio; IQR, interquartile range; MMSE, Mini-Mental State Examination; SBP, systolic blood pressure; SOF, Study of Osteoporotic Fractures.

\section{Declarations}

\section{Ethics approval and consent to participate}

The biomedical ethics committee of Peking University approved the study (IRB00001052-13074). All participants signed written informed consent.

\section{Consent for publication}




\section{Availability of data and material}

This study was based on the datasets from the Chinese Longitudinal Healthy Longevity Survey (CLHLS) in longevity areas. The CLHLS datasets are publicly available at the National Archive of Computerized Data on Aging (NACDA), University of Michigan (https://www.icpsr.umich.edu/icpsrweb/NACDA/series/487). Researchers can obtain these data after submitting a data use agreement to the CLHLS team.

\section{Competing interests}

The authors declare that they have no competing interests.

\section{Funding}

The Chinese Longitudinal Healthy Longevity Study (CLHLS), which provided the data analyzed in this paper, is jointly supported by the National Natural Sciences Foundation of China (81573207, 71233001, 71490732, and 81573247), and the U.S. National Institute of Aging (2P01AG031719 and 3P01AG03171907S1). This work was also supported by the National Key Research and Development Program of China (2018YFC2000400), the Construction of High-level University of Guangdong (C1050008 and C1051007), and the National Institutes of Health (NIH/NIA P30-AG028716). The funders played no role in study design or implementation; data collection, management, analysis, and interpretation; manuscript preparation, review, or approval; or the decision to submit the manuscript for publication.

\section{Authors' contributions}

XBW, XMS and CM designed the study analysis. ZJC, ZF, YBL, YLQ, LL, YCL and JHZ conducted CLHLS and directed its implementation, including quality assurance and control, dataset management and analytic strategy. ZXR and FRL contributed to data cleaning. YBL and ZXY helped supervise the field activities and designed the study's analytic strategy. PLC, HLY, and XC analyzed the data and prepared the manuscript. All authors have critically commented on and revised the manuscript, and approved the final version. XBW and XMS are guarantors of the paper.

\section{Acknowledgements}

Not Applicable. 


\section{Authors' information}

${ }^{1}$ Department of Epidemiology, School of Public Health, Southern Medical University, Guangzhou, Guangdong, China;

${ }^{2}$ National Institute of Environmental Health, Chinese Center for Disease Control and Prevention, Beijing, China.

\section{References}

1. Howcroft TK, Campisi J, Louis GB, Smith MT, Wise B, Wyss-Coray T, et al. The role of inflammation in age-related disease. Aging.2013;5:84-93.

2. Hansson GK. Inflammation, atherosclerosis, and coronary artery disease. N Engl J Med.2005;352:1685-95.

3. Figaro MK, Kritchevsky SB, Resnick HE, Shorr RI, Butler J, Shintani A, et al. Diabetes, inflammation, and functional decline in older adults: findings from the Health, Aging and Body Composition (ABC) study. Diabetes Care.2006;29:2039-45.

4. Holmes C. Review: systemic inflammation and Alzheimer's disease. Neuropathol Appl Neurobiol.2013;39:51-68.

5. Zhang X, Meng X, Chen Y, Leng SX, Zhang H. The Biology of Aging and Cancer: Frailty, Inflammation, and Immunity. Cancer J.2017;23:201-205.

6. Franceschi C, Campisi J. Chronic inflammation (inflammaging) and its potential contribution to ageassociated diseases. J Gerontol A Biol Sci Med Sci.2014;69 Suppl 1:S4-9.

7. Fougère $B$, Boulanger $E$, Nourhashémi $F$, Guyonnet $S$, Cesari M. Retraction to Chronic Inflammation: Accelerator of Biological Aging. J Gerontol A Biol Sci Med Sci.2019;74:431.

8. Marsik C, Kazemi-Shirazi L, Schickbauer T, Winkler S, Joukhadar C, Wagner OF, Endler G. C-reactive protein and all-cause mortality in a large hospital-based cohort. Clin Chem.2008;54:343-9.

9. Pepys MB, Hirschfield GM. C-reactive protein: a critical update. J Clin Invest.2003;111:1805-12.

10. Liu HH, Zhang MW, Guo JB, Li J, Su L. Procalcitonin and C-reactive protein in early diagnosis of sepsis caused by either Gram-negative or Gram-positive bacteria. Ir J Med Sci.2017;186(1):207-212.

11. Guo XS, Lin KY, Li HL, Chen JY, Zhou YL, Liu Y, et al. Preprocedural High-Sensitivity C-Reactive Protein Predicts Contrast-Induced Nephropathy and Long-Term Outcome After Coronary Angiography. Angiology.2017;68(7):614-620.

12. Ye Z, Zhang Z, Zhang H, Hao Y, Zhang J, Liu W, et al. Prognostic Value of C-Reactive Protein and Homocysteine in Large-Artery Atherosclerotic Stroke: a Prospective Observational Study. J Stroke Cerebrovasc Dis.2017;26(3):618-626.

13. Ridker PM. Clinical application of C-reactive protein for cardiovascular disease detection and prevention. Circulation.2003;107:363-9. 
14. Ridker PM. C-reactive protein and the prediction of cardiovascular events among those at intermediate risk: moving an inflammatory hypothesis toward consensus. J Am Coll Cardiol.2007;49:2129-38.

15. Kuoppamäki M, Salminen M, Vahlberg T, Irjala K, Kivelä SL, Räihä I. High sensitive C-reactive protein (hsCRP), cardiovascular events and mortality in the aged: a prospective 9-year follow-up study. Arch Gerontol Geriatr.2015;60:112-7.

16. Tilvis RS, Kähönen-Väre MH, Jolkkonen J, Valvanne J, Pitkala KH, Strandberg TE. Predictors of cognitive decline and mortality of aged people over a 10-year period. J Gerontol A Biol Sci Med Sci.2004;59:268-74.

17. Elkind MS, Luna JM, Moon YP, Liu KM, Spitalnik SL, Paik MC, Sacco RL. High-sensitivity C-reactive protein predicts mortality but not stroke: the Northern Manhattan Study. Neurology.2009;73:1300-7.

18. Arima H, Kubo M, Yonemoto K, Doi Y, Ninomiya T, Tanizaki Y, Hata J, Matsumura K, lida M, Kiyohara Y. High-sensitivity C-reactive protein and coronary heart disease in a general population of Japanese: the Hisayama study. Arterioscler Thromb Vasc Biol.2008;28:1385-91.

19. Koenig W, Khuseyinova N, Baumert J, Meisinger C. Prospective study of high-sensitivity C-reactive protein as a determinant of mortality: results from the MONICA/KORA Augsburg Cohort Study, 19841998. Clin Chem.2008;54:335-42.

20. Makita S, Nakamura M, Satoh K, Tanaka F, Onoda T, Kawamura K,et al. Serum C-reactive protein levels can be used to predict future ischemic stroke and mortality in Japanese men from the general population. Atherosclerosis.2009;204:234-8.

21. Hamer M, Chida Y, Stamatakis E. Association of very highly elevated C-reactive protein concentration with cardiovascular events and all-cause mortality. Clin Chem.2010;56:132-5.

22. .Zuo H, Ueland PM, Ulvik A, Eussen SJ, Vollset SE, Nygård O, et al. Plasma Biomarkers of Inflammation, the Kynurenine Pathway, and Risks of All-Cause, Cancer, and Cardiovascular Disease Mortality: The Hordaland Health Study. Am J Epidemiol.2016;183:249-58.

23. Ahmadi-Abhari S, Luben RN, Wareham NJ, Khaw KT. Seventeen year risk of all-cause and causespecific mortality associated with C-reactive protein, fibrinogen and leukocyte count in men and women: the EPIC-Norfolk study. Eur J Epidemiol.2013;28:541-50.

24. Oluleye OW, Folsom AR, Nambi V, Lutsey PL, Ballantyne CM; ARIC Study Investigators. Troponin T, Btype natriuretic peptide, C-reactive protein, and cause-specific mortality. Ann Epidemiol.2013;23:6673.

25. Shinkai S, Chaves PH, Fujiwara Y, Watanabe S, Shibata H, Yoshida H, Suzuki T. Beta2-microglobulin for risk stratification of total mortality in the elderly population: comparison with cystatin $\mathrm{C}$ and $\mathrm{C}$ reactive protein. Arch Intern Med.2008;168:200-6.

26. Laaksonen DE, Niskanen L, Nyyssönen K, Punnonen K, Tuomainen TP, Salonen JT. C-reactive protein in the prediction of cardiovascular and overall mortality in middle-aged men: a population-based cohort study.Eur Heart J.2005;26:1783-9. 
27. Nisa H, Hirata A, Kohno M, Kiyohara C, Ohnaka K. High-Sensitivity C-Reactive Protein and Risks of AllCause and Cause-Specific Mortality in a Japanese Population. Asian Pac J Cancer Prev.2016;17:2643-8.

28. de Ruijter W, Westendorp RG, Assendelft WJ, den Elzen WP, de Craen AJ, le Cessie S, Gussekloo J. Use of Framingham risk score and new biomarkers to predict cardiovascular mortality in older people: population based observational cohort study. BMJ.2009;338:a3083.

29. Zeng Y. Towards Deeper Research and Better Policy for Healthy Aging --Using the Unique Data of Chinese Longitudinal Healthy Longevity Survey. China Economic J.2012;5:131-149.

30. Folstein MF, Folstein SE, McHugh PR. "Mini-mental state". A practical method for grading the cognitive state of patients for the clinician. J Psychiatr Res.1975;12:189-98.

31. Katzman R, Zhang MY, Ouang-Ya-Qu, Wang ZY, Liu WT, Yu E, Wong SC, Salmon DP, Grant I. A Chinese version of the Mini-Mental State Examination; impact of illiteracy in a Shanghai dementia survey. J Clin Epidemiol.1988;41:971-8.

32. Ensrud KE, Ewing SK, Taylor BC, Fink HA, Cawthon PM, Stone KL, Hillier TA, Cauley JA, Hochberg MC, Rodondi N, Tracy JK, Cummings SR. Comparison of 2 frailty indexes for prediction of falls, disability, fractures, and death in older women. Arch Intern Med.2008;168:382-9.

33. Goggins WB, Woo J, Sham A, Ho SC. Frailty index as a measure of biological age in a Chinese population. J Gerontol A Biol Sci Med Sci.2005;60:1046-51.

34. Writing Group of 2018 Chinese Guidelines for the Management of Hypertension, Chinese Hypertension League, Chinese Society of Cardiology, Chinese Medical Doctor Association Hypertension Committee, Hypertension Branch of China International Exchange and Promotive Association for Medical and Health Care, Hypertension Branch of Chinese Geriatric Medical Association. 2018 Chinese guidelines for the management of hypertension. Chin J Cardiovasc Med.2019;24:24-56.

35. Chinese Diabetes Society, National Offic for Primary Diabetes Care. National guidelines for the prevention and control of diabetes in primary care(2018). Chin J Intern Med.2018;57:885-893.

36. Pearson TA, Mensah GA, Alexander RW, Anderson JL, Cannon RO 3rd, Criqui M, et al. Markers of inflammation and cardiovascular disease: application to clinical and public health practice: $A$ statement for healthcare professionals from the Centers for Disease Control and Prevention and the American Heart Association. Circulation.2003;107:499-511.

37. Lakoski SG, Cushman M, Criqui M, Rundek T, Blumenthal RS, D'Agostino RB Jr, Herrington DM. Gender and C-reactive protein: data from the Multiethnic Study of Atherosclerosis (MESA) cohort. Am Heart J.2006;152:593-8.

38. Kelley-Hedgepeth A1, Lloyd-Jones DM, Colvin A, Matthews KA, Johnston J, Sowers MR, et al. Ethnic differences in C-reactive protein concentrations. Clin Chem.2008;54:1027-37.

39. Dong Y, Wang ZW, Wang X, Tian Y, Zhang LF, Chen Z, Cao HQ. Association between high-sensitivity C-reactive protein and both cardiovascular, total mortality events in middle-aged Chinese adults. Chin J Epidemiol.2018;39:428-432. 
40. Amrock SM, Weitzman M. Effect of increased leptin and C-reactive protein levels on mortality: results from the National Health and Nutrition Examination Survey. Atherosclerosis.2014;236:1-6.

41. Sung KC, Ryu S, Chang Y, Byrne CD, Kim SH. C-reactive protein and risk of cardiovascular and allcause mortality in 268803 East Asians. Eur Heart J.2014;35:1809-16.

42. Doran B, Zhu W, Muennig P. Gender differences in cardiovascular mortality by C-reactive protein level in the United States: evidence from the National Health and Nutrition Examination Survey III. Am Heart J.2013;166:45-51.

43. Asthana A, Johnson HM, Piper ME, Fiore MC, Baker TB, Stein JH. Effects of smoking intensity and cessation on inflammatory markers in a large cohort of active smokers. Am Heart J.2010;160:45863.

\section{Tables}

Table 1. Characteristics of participants by quartiles of C-reactive Protein 


\begin{tabular}{|c|c|c|c|c|c|c|}
\hline & \multirow[t]{3}{*}{ Overall } & \multicolumn{4}{|c|}{ C-reactive Protein ${ }^{\mathrm{a}}$} & \multirow[t]{3}{*}{$\mathrm{P}$} \\
\hline & & $\begin{array}{c}\mathrm{Q} 1 \\
0.27\end{array}$ & $\begin{array}{c}\mathrm{Q} 2 \\
0.75\end{array}$ & $\begin{array}{c}\mathrm{Q} 3 \\
1.76\end{array}$ & $\begin{array}{c}\mathrm{Q} 4 \\
6.59\end{array}$ & \\
\hline & & $\begin{array}{l}(0.17 \\
0.36) \\
\end{array}$ & $\begin{array}{l}(0.61 \\
0.93) \\
\end{array}$ & $\begin{array}{l}(1.40 \\
2.21)\end{array}$ & $\begin{array}{l}(4.07 \\
14.74) \\
\end{array}$ & \\
\hline No. of participants & 2206 & 564 & 547 & 544 & 551 & \\
\hline $\begin{array}{l}\text { Age, median (IQR), } \\
\text { years }\end{array}$ & $\begin{array}{l}93(86, \\
100)\end{array}$ & $\begin{array}{l}93(87 \\
100)\end{array}$ & $\begin{array}{l}92(85, \\
100)\end{array}$ & $\begin{array}{l}92(86, \\
100)\end{array}$ & $\begin{array}{l}94(88, \\
100)\end{array}$ & 0.389 \\
\hline Female, n (\%) & 1417 & 405 & 344 & 336 & 332 & 0.000 \\
\hline Residence, n (\%) & & & & & & 0.102 \\
\hline Urban & $\begin{array}{l}280 \\
(12.81)\end{array}$ & $\begin{array}{l}64 \\
(11.43)\end{array}$ & $\begin{array}{l}58 \\
(10.70)\end{array}$ & $78(14.42)$ & $\begin{array}{l}80 \\
(14.76)\end{array}$ & \\
\hline Rural & $\begin{array}{l}1905 \\
(87.19)\end{array}$ & $\begin{array}{l}496 \\
(88.57)\end{array}$ & $\begin{array}{l}484 \\
(89.30)\end{array}$ & $\begin{array}{l}463 \\
(85.58)\end{array}$ & $\begin{array}{l}462 \\
(85.24)\end{array}$ & \\
\hline Education time, years & & & & & & 0.706 \\
\hline 0 & $\begin{array}{l}1714 \\
(78.41)\end{array}$ & $\begin{array}{l}444 \\
(79.86)\end{array}$ & $\begin{array}{l}417 \\
(76.94)\end{array}$ & $\begin{array}{l}424 \\
(78.23)\end{array}$ & $\begin{array}{l}429 \\
(78.57)\end{array}$ & \\
\hline$\geq 1$ & $\begin{array}{l}472 \\
(21.59)\end{array}$ & $\begin{array}{l}112 \\
(20.14)\end{array}$ & $\begin{array}{l}125 \\
(23.06)\end{array}$ & $\begin{array}{l}118 \\
(21.77)\end{array}$ & $\begin{array}{l}117 \\
(21.43)\end{array}$ & \\
\hline Smoking status, n (\%) & & & & & & 0.986 \\
\hline Current & $\begin{array}{l}220 \\
(10.22)\end{array}$ & $\begin{array}{l}56 \\
(10.13)\end{array}$ & $53(9.98)$ & $54(10.13)$ & $\begin{array}{l}57 \\
(10.63)\end{array}$ & \\
\hline Not current & $\begin{array}{l}1933 \\
(8078)\end{array}$ & 497 & 478 & 479 & $\begin{array}{l}479 \\
(8937)\end{array}$ & \\
\hline $\begin{array}{l}\text { Alcohol drinking status, } \\
\text { n (\%) }\end{array}$ & & & & & & 0.780 \\
\hline Current & 254 & 68 & 67 & $61(11.47)$ & 58 & \\
\hline Not current & $\begin{array}{l}1896 \\
(8819)\end{array}$ & 483 & 463 & 471 & $\begin{array}{l}479 \\
(8920)\end{array}$ & \\
\hline $\begin{array}{l}\text { Frequent vegetable } \\
\text { intake, } \mathrm{n}(\%)^{\mathrm{b}}\end{array}$ & $\begin{array}{l}1240 \\
(57.57)\end{array}$ & $\begin{array}{l}309 \\
(55.98)\end{array}$ & $\begin{array}{l}325 \\
(61.21)\end{array}$ & $\begin{array}{l}315 \\
(59.10)\end{array}$ & $\begin{array}{l}291 \\
(54.09)\end{array}$ & 0.085 \\
\hline $\begin{array}{l}\text { Frequent fruit intake, } \mathrm{n} \\
(\%)^{\mathrm{b}}\end{array}$ & $\begin{array}{l}795 \\
(36.75)\end{array}$ & $\begin{array}{l}223 \\
(40.11)\end{array}$ & $\begin{array}{l}205 \\
(38.46)\end{array}$ & $\begin{array}{l}203 \\
(37.94)\end{array}$ & $\begin{array}{l}164 \\
(30.43)\end{array}$ & 0.005 \\
\hline $\begin{array}{l}\text { Frequent meat intake, } \\
\mathrm{n}(\%)^{\mathrm{b}}\end{array}$ & $\begin{array}{l}1024 \\
(48.51)\end{array}$ & $\begin{array}{l}251 \\
(45.72)\end{array}$ & $\begin{array}{l}271 \\
(52.62)\end{array}$ & $\begin{array}{l}277 \\
(53.47)\end{array}$ & $\begin{array}{l}225 \\
(42.53)\end{array}$ & 0.000 \\
\hline $\begin{array}{l}\text { Habitual exercise, } \mathrm{n} \\
(\%)^{\mathrm{c}}\end{array}$ & $\begin{array}{l}263 \\
(12.51)\end{array}$ & $\begin{array}{l}82 \\
(15.27)\end{array}$ & $\begin{array}{l}63 \\
(12.14)\end{array}$ & $61(11.66)$ & $\begin{array}{l}57 \\
(10.90)\end{array}$ & 0.146 \\
\hline Medical history & & & & & & \\
\hline Hypertension, n (\%) & $\begin{array}{l}841 \\
(38.12)\end{array}$ & $\begin{array}{l}254 \\
(45.04)\end{array}$ & $\begin{array}{l}201 \\
(36.75)\end{array}$ & $\begin{array}{l}191 \\
(35.11)\end{array}$ & $\begin{array}{l}195 \\
(35.39)\end{array}$ & 0.000 \\
\hline Diabetes, n (\%) & 189 & $34(6.03)$ & $38(6.95)$ & $58(10.66)$ & $36(6.53)$ & 0.005 \\
\hline CVD, n (\%) & 311 & 71 & 69 & $83(15.26)$ & 88 & 0.405 \\
\hline Frailty & & & & & & 0.002 \\
\hline Frail, n (\%) & 740 & $\begin{array}{l}194 \\
(3440)\end{array}$ & $\begin{array}{l}159 \\
(290\end{array}$ & 168 & $\begin{array}{l}219 \\
397\end{array}$ & \\
\hline Prefrail, n (\%) & 753 & 193 & 189 & 186 & 185 & \\
\hline Robust, n (\%) & 713 & 177 & 199 & 190 & 147 & \\
\hline MMSE, median (IQR) & $25(18$, & 25 (17, & 26 (19, & 26 (19, & 24 (16, & 0.321 \\
\hline $\begin{array}{l}\text { BMI, median (IQR), } \\
\mathrm{kg} / \mathrm{m}^{2}\end{array}$ & 20.00 & 19.48 & 20.41 & 20.34 & 19.93 & 0.461 \\
\hline
\end{tabular}




\begin{tabular}{lllllll} 
& $(17.78$, & $(17.58$, & $(18.29$, & $(18.03$, & $(17.78$, & \\
& $22.81)$ & $22.03)$ & $23.45)$ & $22.96)$ & $22.75)$ & \\
Systolic pressure, & $140(126$, & $143(130$, & $140(128$, & 141.5 & $140(121$, & 0.000 \\
median (IQR), mmHg & $160)$ & $160)$ & $160)$ & $(127.5$, & $155.5)$ & \\
Total cholesterol, & 4.31 & 4.38 & 4.33 & $4.43(3.78$, & $4.07(3.5$, & 0.014 \\
median (IQR), mmol/L & $(3.67$, & $(3.68$, & $(3.75$, & $5.17)$ & $4.83)$ & \\
Triglycerides, median & $5.02)$ & $5.02)$ & $5.02)$ & & \\
(IQR), mmol/L & 0.86 & 0.83 & 0.88 & $0.92(0.67$, & 0.84 & 0.132 \\
Glucose, median (IQR), & $(0.64$, & $(0.61$, & $(0.66$, & $1.28)$ & $(0.63$, & \\
mmol/L & 4.68 & $1.12)$ & $1.23)$ & & \\
& $(4.00$, & $(3.48$ & 4.71 & $4.80(4.10$, & 4.69 & 0.001 \\
& $5.45)$ & $5.17)$ & $(4.07$, & $5.54)$ & $(3.96$, & \\
\hline
\end{tabular}

${ }^{\text {a }}$ Quartiles of C-reactive Protein: median (IQR), mg/L

b "Frequent intake" was defined by the frequencies of "almost every day" or "often".

c "Habitual exercise" was defined as "exercise at present".

Table 2. Association between CRP and all-cause mortality

\begin{tabular}{llll}
\hline & \multicolumn{2}{c}{ HR [95\% CI] ${ }^{\mathrm{a}}$ for all-cause mortality } \\
\cline { 2 - 4 } & \multicolumn{1}{c}{ Model 1 } & \multicolumn{1}{c}{ Model 2} & Model 3 \\
\hline Risk by quartiles & \multicolumn{1}{c}{ } & \multicolumn{1}{c}{} \\
Q1 & 1.00 (reference) & 1.00 (reference) & 1.00 (reference) \\
Q2 & $1.15(0.94,1.40)$ & $1.10(0.89,1.36)$ & $1.17(0.94,1.46)$ \\
Q3 & $1.27(1.03,1.55)$ & $1.24(1.00,1.53)$ & $1.28(1.01,1.61)$ \\
Q4 & $1.54(1.27,1.86)$ & $1.50(1.23,1.84)$ & $1.50(1.20,1.87)$ \\
P-trend & 0.000 & 0.000 & 0.000 \\
Risk by levels & & & \\
<1.0 & 1.000 (reference) & 1.000 (reference) & 1.000 (reference) \\
1-3.0 & $1.171(0.98,1.39)$ & $1.18(0.98,1.41)$ & $1.17(0.96,1.42)$ \\
>3.0 mg/L & $1.45(1.22 .1 .71)$ & $1.44(1.21,1.73)$ & $1.39(1.15,1.70)$ \\
P-trend & 0.000 & 0.000 & 0.001 \\
\hline
\end{tabular}

${ }^{a} \mathrm{HR}$ : hazard ratio; CI: confidence interval;

Model 1: adjusted for age, sex.

Model 2: adjusted for age, sex, education, residence, smoking, drinking, exercise, fruit intake, meat intake, vegetable intake.

Model 3: adjusted for age, sex, education, residence, smoking, drinking, exercise, fruit intake, meat intake, vegetable intake, BMI, MMSE, frailty, hypertension, diabetes, CVD, cholesterol, triglycerides. 
Table 3. Subgroup analyses for the hazard ratio of all-cause mortality for each $10 \mathrm{mg} / \mathrm{L}$ increase in CRP

\begin{tabular}{|c|c|c|}
\hline Subgroup & $\operatorname{HR}[95 \% \mathrm{CI}]^{\mathrm{a}}$ & P-interaction \\
\hline \multicolumn{2}{|l|}{ Aqe } & \multirow{4}{*}{0.214} \\
\hline $80+$ years & $1.02(0.85,1.23)$ & \\
\hline $90+$ years & $1.04(0.93,1.16)$ & \\
\hline $100+$ years & $1.23(1.05,1.45)$ & \\
\hline \multicolumn{2}{|l|}{ Sex } & \multirow[t]{2}{*}{0.135} \\
\hline $\begin{array}{l}\text { Woman } \\
\text { Man }\end{array}$ & $1.16(1.04,1.29)$ & \\
\hline \multicolumn{2}{|l|}{ Education time } & \multirow{3}{*}{0.226} \\
\hline 0 year & $1.11(1.02,1.20)$ & \\
\hline $\begin{array}{l}\geq 1 \text { year } \\
\text { Residence }\end{array}$ & $0.92(0.68,1.24)$ & \\
\hline Residence & & \multirow[t]{2}{*}{0.418} \\
\hline $\begin{array}{l}\text { Urban } \\
\text { Rural }\end{array}$ & $0.95(0.76,1.18)$ & \\
\hline \multicolumn{2}{|l|}{ Smoking status } & \multirow{3}{*}{0.011} \\
\hline Current & $0.83(0.66,1.03)$ & \\
\hline Not current & $1.17(1.07,1.28)$ & \\
\hline \multicolumn{2}{|l|}{ Drinking status } & \multirow{2}{*}{0.446} \\
\hline $\begin{array}{l}\text { Current } \\
\text { Not current }\end{array}$ & $0.98(0.68,1.40)$ & \\
\hline \multicolumn{2}{|c|}{ Habitual exercise } & \multirow[t]{3}{*}{0.820} \\
\hline Yes & $1.02(0.631 .67)$ & \\
\hline No & $1.08(1.00,1.17)$ & \\
\hline \multicolumn{2}{|l|}{ Vegetable intake } & \multirow[t]{2}{*}{0.289} \\
\hline $\begin{array}{l}\text { Often } \\
\text { Not often }\end{array}$ & $\begin{array}{l}1.16(1.00,1.34) \\
1.05(0.95,1.16)\end{array}$ & \\
\hline \multicolumn{2}{|l|}{ Fruit intake } & \multirow[t]{2}{*}{0.125} \\
\hline $\begin{array}{l}\text { Often } \\
\text { Not often }\end{array}$ & $1.18(0.98,1.43)$ & \\
\hline \multicolumn{2}{|l|}{ Meat intake } & \multirow[t]{2}{*}{0.646} \\
\hline $\begin{array}{l}\text { Often } \\
\text { Not often }\end{array}$ & $1.07(0.89,1.29)$ & \\
\hline \multicolumn{2}{|l|}{$\begin{array}{l}\text { Not often } \\
\text { BMI }\end{array}$} & \multirow{3}{*}{0.798} \\
\hline$<18.5$ & $1.14(0.98,1.32)$ & \\
\hline $\begin{array}{l}\geq 18.5 \text { and }<24 \\
\geq 24\end{array}$ & $1.04(0.94,1.16)$ & \\
\hline \multirow{2}{*}{$\begin{array}{l}\text { MMSE scores } \\
<24 \\
\geq 24\end{array}$} & & \multirow[t]{2}{*}{0.556} \\
\hline & $\begin{array}{l}1.10(1.00,1.21) \\
1.05(0.91,1.21)\end{array}$ & \\
\hline \multicolumn{2}{|l|}{ Frailty } & \multirow[t]{4}{*}{0.784} \\
\hline Frail & $1.08(0.95,1.22)$ & \\
\hline Prefrail & $1.10(0.97,1.25)$ & \\
\hline Robust & $1.00(0.81,1.23)$ & \\
\hline
\end{tabular}

${ }^{\text {a } H R: ~ h a z a r d ~ r a t i o ; ~ C I: ~ c o n f i d e n c e ~ i n t e r v a l . ~}$

HRs were adjusted for age, sex, education, residence, smoking, drinking, exercise, fruit intake, meat intake, vegetable intake, BMI, MMSE, frailty, hypertension, diabetes, CVD, cholesterol, triglycerides. 


\section{Figures}

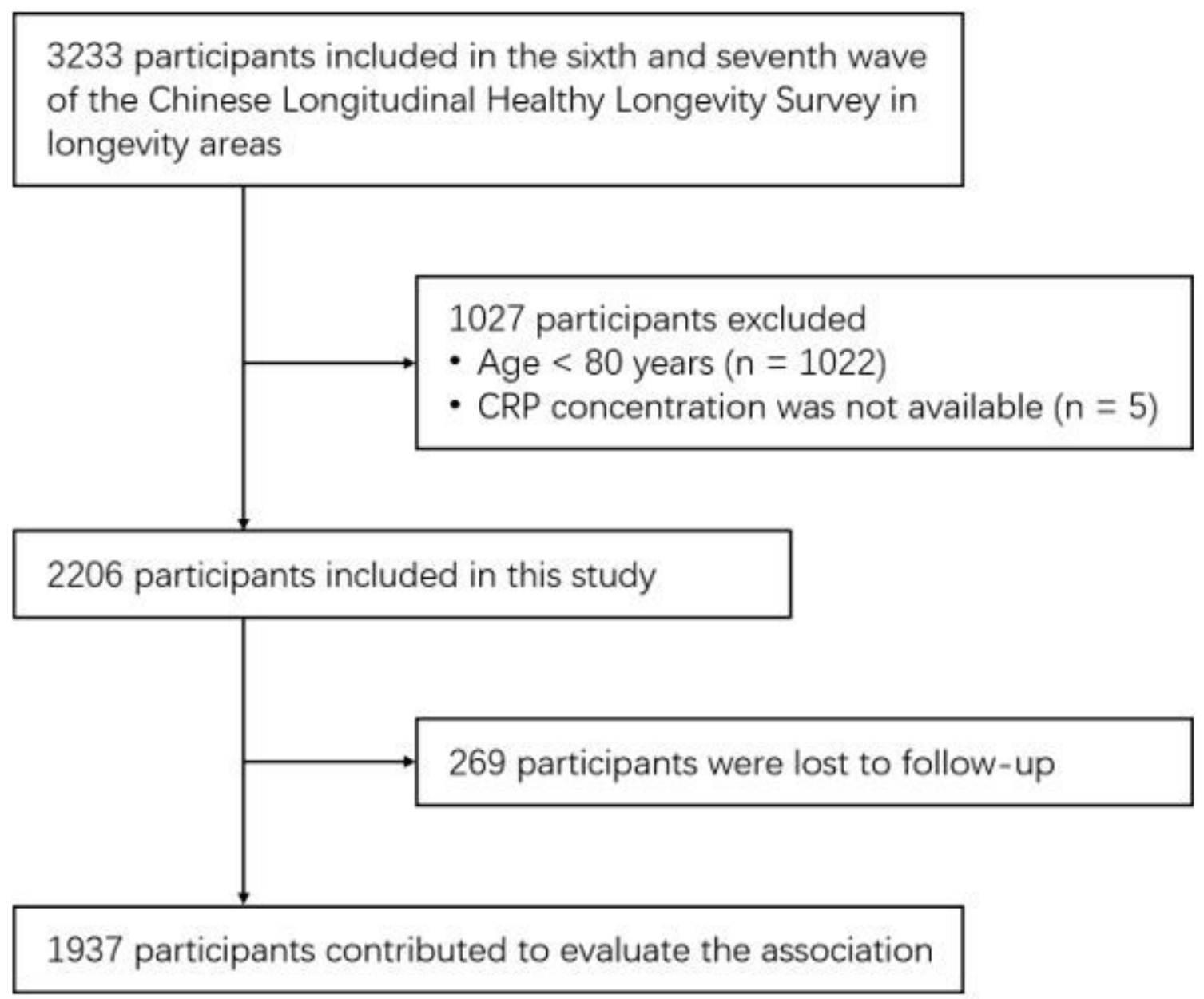

\section{Figure 1}

Flowchart of participant enrollment 


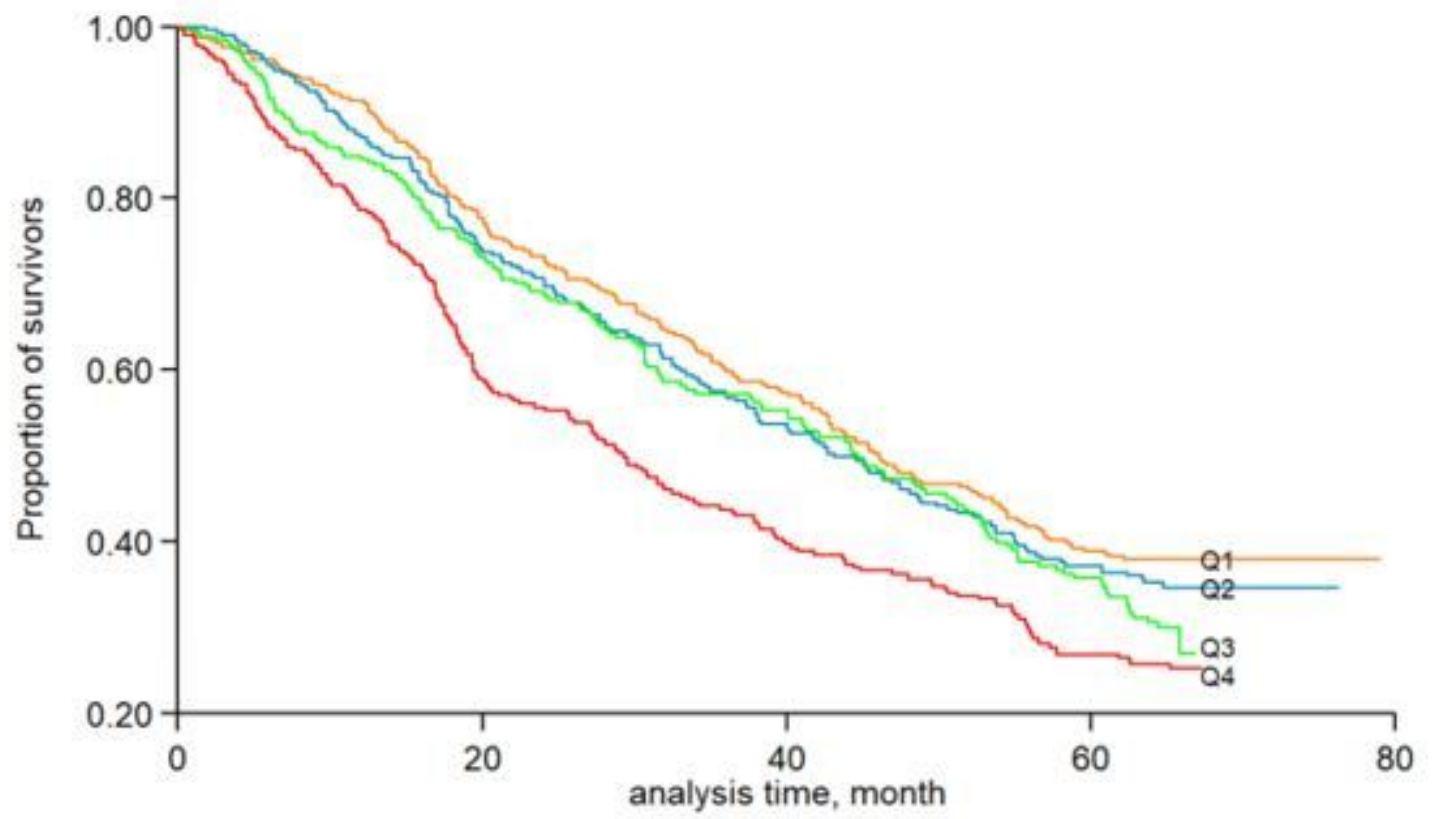

Number at risk

\begin{tabular}{llllll} 
Q1 & 360 & 280 & 178 & 121 & 0 \\
Q2 & 308 & 228 & 140 & 97 & 0 \\
Q3 & 272 & 199 & 119 & 77 & 0 \\
Q4 & 314 & 185 & 106 & 72 & 0 \\
& & Q1 & Q2 & Q3 & \\
\cline { 2 - 3 } & & &
\end{tabular}

Figure 2

Kaplan-Meier graphs for all-cause mortality by quartiles of CRP 